\title{
Enzymatic hydrolysis of potato starches containing different amounts of phosphorus.
}

\begin{abstract}
The rapid hydrolysis of potato starches differing in phosphorus content, as well as sweet potato, cassava and yam starches, was accomplished by treatment of gelatinised starches with bacterial liquefying $\alpha$-amylase at $50{ }^{\circ} \mathrm{C}$ for $1 \mathrm{~h}$, followed by Bacillus licheniformis $\alpha$-amylase at $55^{\circ} \mathrm{C}$ up to $24 \mathrm{~h}$, and then by glucoamylase at $40{ }^{\circ} \mathrm{C}$ for a further $24 \mathrm{~h}$. Among the potato starches, the high-phosphorus starches showed higher starch resistant capacity than the medium-phosphorus starches, as well as other tuber and root starches. The hydrolysis rate of tuber and root starches was not greatly influenced by their amylose content and median granule size. Only glucose was detected in the almost completely hydrolysed tuber and root starch samples, indicating that the concomitant enzymes treatment could hydrolyse both the $\alpha-1,4$ and $\alpha-1,6$ linkages of the starches examined.
\end{abstract}

Keyword: Gelatinised potato starches; Phosphorus content; a-Amylase; Glucoamylase. 